\title{
Yield and yield components of chickpea as affected by various levels of FYM and rhizobium inoculation
}

Farooq Nawaz ${ }^{1}$, Nangial Khan ${ }^{1 *}$, Junaid Ali Shah ${ }^{2}$, Abdullah Khan ${ }^{3}$, Adeel Liaqat ${ }^{1}$, Saif Ullah ${ }^{1}$, Anis Ur Rehman Khalil ${ }^{2}$, Talha Jan ${ }^{1}$, Shahid Ullah $^{1}$, Mehran Ali ${ }^{1}$, Sohail ${ }^{2}$ and Murad $\mathrm{Ali}^{3}$

1. Department of Agronomy, The University of Agriculture Peshawar-Pakistan

2. Department of Water management, The University of Agriculture Peshawar-Pakistan

3. Department of Horticulture, The University of Agriculture Peshawar-Pakistan

*Corresponding author's email: nangialkhan@ hotmail.com

Citation

Farooq Nawaz, Nangial Khan, Junaid Ali Shah, Abdullah Khan, Adeel Liaqat, Saif Ullah, Anis Ur Rehman Khalil, Talha Jan, Shahid Ullah, Mehran Ali, Sohail and Murad Ali. Yield and yield components of chickpea as affected by various levels of FYM and rhizobium inoculation. Pure and Applied Biology. Vol. 6, Issue 1, pp346-351. http://dx.doi.org/10.19045/bspab.2017.60033

Received: 04/11/2016

Revised: 22/02/2017

Accepted: 28/02/2017

Online First: 02/03/2017

\section{Abstract}

The experiment was conducted at the Agronomy Research Farm, The University of Agriculture, Peshawar, Pakistan during winter 2015 in a simple randomized complete block design (RCBD) having three replications. Farmyard manure (FYM) application at four levels (0, 5, 10, and 15 ton $\mathrm{ha}^{-1}$ ) with variety (Inoculated and non-inoculated) were included in experiment. FYM application at the rate of 15 ton ha ${ }^{-1}$ resulted in higher grain yield $\left(2198.53 \mathrm{~kg} \mathrm{ha}^{-1}\right)$ as compared to control (1762.68 $\left.\mathrm{kg} \mathrm{ha}^{-1}\right)$. Similarly inoculated seeds produced higher grain yield $(2083.06 \mathrm{~kg}$ $\left.\mathrm{ha}^{-1}\right)$ as compared to non-inoculated seeds $\left(1915.92 \mathrm{~kg} \mathrm{ha}^{-1}\right)$. The pods plant ${ }^{-1}$ and thousand grain weight were significantly affected by FYM and inoculation while grains pod ${ }^{-1}$ was significantly affected by only FYM. The grains were more pod $^{-1}$ in plots supplied with 15 tons FYM ha-1 while less number of grains pod $^{-1}$ (1.48) resulted in control plots. Plants formed more pods (63.68) and maximum thousand grain weight $(260.21 \mathrm{~g}$ ) was calculated in plots treated with FYM at the rate of 15 ton $^{-1}$ as compared to other levels. In the same way more pods plant ${ }^{1}(58.44)$ and thousand grain weight (241.65 g) was observed in plots with inoculated seed sown. Hence application of FYM at the rate of 15 ton ha ${ }^{-1}$ and inoculation of seeds with rhizobium strains is recommended for better yield of chick pea.

Keywords: ChickPea; Farm yard manure; Rhizobium Inoculation

\section{Introduction}

Chickpea (Cicer arietinum L.) is an important winter pulse crop. It belongs to genus Cicer and family Fabaceae. "Cicer" is of Latin origin and the derivative of the Greek word 'kikus' meaning force or strength [1]. The word "arietinum" is also of Latin origin. It is equivalent to Greek word 'krios' used for chickpea [2]. In grain legumes, it is ranked third after bean and soyabean growing in the world. The chickpea has agronomical significance 
because of its high protein content (approx. $19.3-25.4 \%$ ).It is used for the human and animal's diet. It is the alternative protein source. It originated in south-eastern Turkey [3]. The archaeological evidences show that earliest domestication of chickpea occurred in Middle East and Indo-Pak sub-continent.

Chickpea is classified into two classes morphologically; kabuli and desi. Kabuli type is distinguished by large leaflets, white flowers, medium to tall (up to $1 \mathrm{~m}$ ) height, large, round and cream colour seeds. This type lack anthocyanin pigmentation. While desi type has small angular shaped seeds varying from black, brown, yellow to green. Plants are short with small leaflets, purplish flowers and also contain anthocyanin pigmentation $[4,5]$.

Chickpea seeds are consumed fresh as green vegetables, fried, roasted and boiled. Seeds are ground and the flour can be used as soup and to make bread [6]. It is also used as fodder for livestock.

In world, Pakistan ranked second (842 thousand tonnes) in the production of chickpea after India (5970 thousand tonnes) [7]. In total cropped area of Pakistan, 7\% area is under the cultivation of pulses; $73 \%$ is under chickpea cultivation. Its production in Pakistan was 496 thousand tones. It was cultivated on 1055 thousand ha. The average yield was $471 \mathrm{~kg} \mathrm{ha}^{-1}$ [7]. In Khyber Pakhtunkhwa the production was 21 thousand tons. It was cultivated on an area of 37.6 thousand ha with an average yield of $532 \mathrm{~kg} \mathrm{ha}^{-1}$ [8]. In Khyber Pakhtunkhwa chickpea cultivation concerning $75 \%$ occurs in rainfed areas.

Plants need amino acid to form proteins. Nitrogen $(\mathrm{N})$ is a key element for the production of amino acids. Nitrogen also helps in plant metabolism. Atmospheric nitrogen is not utilized by plants. Plants utilize it in ionic form either nitrate $\left(\mathrm{NO}_{3}{ }^{-}\right)$ or ammonium $\left(\mathrm{NH}_{4}^{+}\right)$. The productivity of cropping system can be sustained by chickpea due to the reason that it fix atmospheric nitrogen. Chickpea root system have specialized structures called nodules where Rhizobium inhabits. Rhizobium has the capability to fix atmospheric nitrogen to plants usable form. It is called biological nitrogen fixation (BNF). The $\mathrm{N}$ fixed through BNF is utilized by both crops; the present crop and the subsequent crop [9]. The maximum $\mathrm{N}$ fixation depends upon the cultivar, nodules number and the competent strain of the Rhizobia existing in the root nodules.

The actual yield of chickpea is very low in field conditions. It is due to minimum or unavailability of good quality seeds, lack of effective Rhizobial strain and severe injury caused by the attack of pod borer and blight. In addition, the soil of Pakistan is generally deficient in $\mathrm{N}$; as its involvement is essential for plant metabolism and protein synthesis. Nitrogen deficiency in soil usually reduces crop yield. Inoculation of chickpea seeds by artificial means in such soils which are deficient in native effective Rhizobia is a very useful practice for improving root nodulation and yield of the crop [10].

Increasing and extending the role of biofertilizers such as Rhizobium can reduce the need for chemical fertilizers and decrease adverse environmental effects. As legume, chickpea can obtain a significant portion (4-85\%) of its $\mathrm{N}$ requirement through symbiotic $\mathrm{N}_{2}$ fixation when grown in association with effective and compatible Rhizobium strains [11-13]. Chickpea and Rhizobium leguminosarum sub spp. Ciceri association annually produces up to $176 \mathrm{~kg}$ $\mathrm{N} \mathrm{ha}^{-1}$ depending on cultivar, bacterial strain and environmental factors [14].

\section{Materials and methods}

The present study was conducted at Agronomy Research Farm, The University of Agriculture, Peshawar during the cropping season 2014-15. Chickpea variety (karak-03) was evaluated under inoculated 
and uninoculated conditions subjected to four different farmyard manure levels. The experiment was plotted in RCB Design with four replications. Each Variety was planted in six rows of $3 \mathrm{~m}$ in length. Row-row distance was $30 \mathrm{~cm}$ and plant-plant was $10 \mathrm{~cm}$. All recommended practices and inputs were homogeneously applied to each experimental unit.

Factor "A"

FYM $(0,5,10,15$ tons ha-1)

Factor "B"

Rhizobium inoculated seeds and uninoculated seeds.

The below parameters were evaluated as;

\section{Number of pods plant ${ }^{-1}$}

Pods were taken from randomly selected plants and counted separately after harvesting. The data on pods of all the selected plants were added and then found its average.

\section{Number of grains pod $^{-1}$}

The total number of grains in each pod were counted from ten randomly selected pods from indiscriminately chosen plants and then averaged.

\section{Thousand grains weight (g)}

A sample of thousand grains was taken from the unvaryingly selected plants and was weighed on a balance to record its mass in grams.

\section{Grain yield (kg ha-1)}

Grain yield was recorded from randomly selected area of an $\mathrm{m}^{2}$ and then converted to hectare.

Grain yield $\left(\mathrm{kgha}^{-1}\right)=\frac{\text { Grain yield }}{\text { Row-row }} 10000$
distance x Row length x No. of rows

\section{Statistical analysis}

Data was analysed by using statistical package 'Statistix 8.1'.

\section{Results and discussion}

Pods plant ${ }^{-1}$

Data regarding pods plant ${ }^{-1}$ is expressed in Table 1. From analysis it was concluded that the response of farmyard manure (FYM) and inoculation were statistically significant. Farm yard manure applied at the rate of 15 tons $^{-1}$ gave more number of podsplant ${ }^{-1}$ (63.68) in response to control in which the pods plant $^{-1}$ decreased (52.72).Similarly inoculated variety formed more pods plant $^{-1}$ (58.44) than non-inoculated variety which was less in number (55.14). The augmentation of FYM developed more pods in plants due to more pronounced growth of the plant [15]. Rhizobium inoculation in chick pea quantify the pods in plants in momentous way $[13,16]$.

Table 1. Number of pod per plant of chick pea as affected by farm yard manure and inoculation

\begin{tabular}{|l|l|l|l|}
\hline Farmyard manure $\left(\mathbf{k g ~ h a}^{-1}\right)$ & Inoculation & Non-inoculation & Mean \\
\hline Control & 48.23 & 57.2 & $52.72 \mathrm{~b}$ \\
\hline 5 & 52.32 & 55.45 & $53.88 \mathrm{~b}$ \\
\hline 10 & 58.32 & 55.45 & $56.88 \mathrm{~b}$ \\
\hline 15 & 61.7 & 65.67 & $63.68 \mathrm{a}$ \\
\hline Mean & $55.14 \mathrm{~b}$ & $58.44 \mathrm{a}$ & \\
\hline
\end{tabular}

Means followed by different letters in the same category are significantly different using LSD test $(\mathrm{P} \leq 0.05)$

$\mathrm{LSD}$ value for $\mathrm{FYM}=4.66$

LSD value for Inoculation $=3.29$

\section{Grains pod ${ }^{-1}$}

Results of the data pertaining grains pod $^{-1}$ (Table 2) showed the significant response of FYM. The inoculation and non-inoculation of variety and the interaction between them have no significant effect in statistical way. The submission of FYM at the rate of 15 tons $\mathrm{ha}^{-1}$ to the plots resulted in increasing the grains number $\operatorname{pod}^{-1}(2.26)$ whereas control plot having no FYM gave fewer number of 
grains $\operatorname{pod}^{-1}(1.48)$. These results stated that with each increment in FYM the number of grains $\operatorname{pod}^{-1}$ increases due to more pronounced growth of the plant because FYM release nutrient specially nitrogen that enhances above ground plant growth [16].

Table 2. Number of grain per pod of chick pea as affected by farm yard manure and inoculation

\begin{tabular}{|l|l|l|l|}
\hline Farmyard manure $\left(\mathbf{k g ~ h a}^{-\mathbf{1}}\right)$ & Inoculation & Non-inoculation & Mean \\
\hline Control & 1.21 & 1.75 & $1.48 \mathrm{~b}$ \\
\hline 5 & 1.82 & 2.1 & $1.96 \mathrm{ab}$ \\
\hline 10 & 2.2 & 2.17 & $2.19 \mathrm{a}$ \\
\hline 15 & 2.2 & 2.33 & $2.26 \mathrm{a}$ \\
\hline Mean & 1.86 & 2.09 & \\
\hline
\end{tabular}

Means followed by different letters in the same category are significantly different using LSD test $(\mathrm{P} \leq 0.05)$

$\mathrm{LSD}$ value for $\mathrm{FYM}=0.52$

\section{Thousand grain weight (g)}

Statistical analysis of the data of Table 3 pointed out that FYM levels and inoculation caused significant variation in thousand grains weight. The interaction between them was found in significant. Heavier grains $(260.21 \mathrm{~g})$ formed in plots treated with 15 tons of FYM ha- ${ }^{-1}$ while lighter grains
$(207.33 \mathrm{~g})$ were formed in control plots. Likewise, the inoculated variety gave better performance and maximum weight of grains $(241.65 \mathrm{~g})$ was achieved than non-inoculated variety which has minimum grains weight (227.34 g).Our results are in conformity with [17] in which the inoculated variety has a positive impact on thousand grains weight.

Table 3. Thousand grains weight of chick pea as affected by farm yard manure and inoculation

\begin{tabular}{|c|c|c|c|}
\hline Farmyard manure $\left(\mathrm{kg} \mathrm{ha}^{-1}\right)$ & inoculation & Non-inoculation & Mean \\
\hline Control & 194.41 & 220.25 & $207.33 \mathrm{~b}$ \\
\hline 5 & 225.33 & 220.78 & $223.05 \mathrm{~b}$ \\
\hline 10 & 233.45 & 261.37 & $247.41 \mathrm{a}$ \\
\hline 15 & 256.2 & 264.22 & $260.21 \mathrm{a}$ \\
\hline Mean & $227.344 \mathrm{~b}$ & $241.656 \mathrm{a}$ & \\
\hline
\end{tabular}

Means followed by different letters in the same category are significantly different using LSD test $(\mathrm{P} \leq 0.05)$

LSD value for FYM = 20.03

LSD value for Inoculation $=14.16$

\section{Grain yield $\left(\mathrm{kg} \mathrm{ha}^{-1}\right)$}

According to the statistical analysis of data, application of FYM and varietal inoculation and non-inoculation had a significant effect on grain yield (Table 4). The interaction among them was of no significant value. Lofty grain yield $\left(2198.53 \mathrm{~kg} \mathrm{ha}^{-1}\right)$ was observed by FYM application at the rate of 15 tons $\mathrm{ha}^{-1}$ while the control plot gave lower grain yield $\left(1762.68 \mathrm{~kg} \mathrm{ha}^{-1}\right)$. These results are in harmony with those of $[18,19]$ they observed positive effect of FYM application on yield of chickpea. The inoculated variety produced more grain yield (2083.06 $\left.\mathrm{kg} \mathrm{ha}^{-1}\right)$ as compared to noninoculated variety $\left(1915.92 \mathrm{~kg} \mathrm{ha}^{-1}\right)$. Our results are supported by [20] in which inoculation improved grain yield in chick pea. 
Table 4. Grain yield of chick pea as affected by farm yard manure and inoculation

\begin{tabular}{|l|l|l|l|}
\hline Farmyard manure $\left(\mathbf{k g ~ h a}^{-1}\right)$ & inoculation & Non-inoculation & Mean \\
\hline Control & 1614.4 & 1910.96 & $1762.68 \mathrm{c}$ \\
\hline 5 & 1887.96 & 1984.82 & $1936.39 \mathrm{bc}$ \\
\hline 10 & 2042.88 & 2157.83 & $2100.36 \mathrm{ab}$ \\
\hline 15 & 2118.44 & 2278.62 & $2198.53 \mathrm{a}$ \\
\hline Mean & $1915.92 \mathrm{~b}$ & $2083.06 \mathrm{a}$ & \\
\hline
\end{tabular}

Means followed by different letters in the same category are significantly different using LSD test $(\mathrm{P} \leq 0.05)$

LSD value for FYM = 175.005

LSD value for Inoculation $=123.74$

\section{Conclusion and recommendation}

Following conclusions were made from the findings of this research;

1. Farmyard manure applied at the rate of 15 $\mathrm{t} \mathrm{ha}^{-1}$ gave us high yield as compare to other levels.

2. Inoculated seed gave us better yield as compared to non-inoculated seed.

Application of FYM at the rate of 15 tons ha

1 and inoculation with rhizobium strains is recommended for better yield of chick pea.

Authors' contributions

Conceived and designed the experiment: N Khan \& F Nawaz, Performed the experiments: F Nawaz, S Ullah, M Ali \& A Liaqat, Analyzed the data: JA Shah, A Khan, \& AUR Khalil, Contributed reagents/ materials/ analysis tools: T Jan, S Ullah, M Ali \& Sohail, Wrote the paper: N Khan.

\section{References}

1. Duschak M (1871). ZurBotanik des Talmud. I. Neuer. Pest 105-106.

2. Van der Maesen LJG (1987). Origin, history and taxonomy of chickpea. In The chickpea. In: Saxena M.C., Singh K.B. (eds.): The Chickpea. CAB Inter., Wallingford: 11-34.

3. Ladizinsky G (1975). A new Cicer from Turkey. Notes from the Royal Botanic Garden, Edinburgh 34: 201-202.

4. Muehlbauer FJ, Short RW \& Kaiser WJ (1982). Description and Culture of Garbanzo Beans. Coop. Ext. Publ. EB 1112, Washington St. Univ, Pullman.

5. Cubero JI (1975). The research on chickpea (Cicer arietinum L.) in Spain
Proceedings of the international workshop on Grain Legumes, ICRISAT, Hyderabad, India. p. 117-122.

6. Hulse JH (1989). Nature, composition and utilization of grain legumes. 1991. In: Uses of tropical legumes. Pages 11-27 in proceedings of a Consultant's Meeting, 27-30 March, ICRISAT Center. ICRISAT, Patancheru, A.P. 502-324, India.

7. FAOSTAT (2010-11). Food and Agriculture Organization of the United Nations, FAO Statistical Databases. Availible at http//.faostat.fao.org.

8. FBS (2010-11). Federal Bureau of Statistics. Ministry of Economic Affairs and Statistics Islamabad, Pak.

9. Khattak SG, Khan DF, Shah SH, Madani MS \& Khan T (2006). Role of Rhizobial inoculation in the production of Chickpea crop. Soil and Environ 25(2): 143-145.

10. Rupela OP \& Dart PJ (1979). Research on symbiotic nitrogen fixation by chickpea at ICRISAT. p. 162-167. In: Proc. International Workshop on Chickpea Improvement, Feb. 8 to March 2, 1979, Hyderabad, India.

11. Saini VK, Bhandari SC \& Tarafdar JC (2004). Comparison of crop yield, soil microbial $\mathrm{C}, \mathrm{N}$ and $\mathrm{P}, \mathrm{N}$-fixation, nodulation and mycorrhizal infection in inoculated and non-inoculated sorghum and chickpea crops. Field Crops Research 89: 39-47.

12. Rudresh DL, Shivaprakash MK \& Prasad RD (2005). Effect of combined 
application of Rhizobium, phosphate solubilizing bacterium and Trichoderma spp. on growth, nutrient uptake and yield of chickpea (Cicer aritenium L.). Applied Soil Ecology 28: 139-146.

13. Togay N, Togay Y, Cimrin KM \& Turan M (2008). Effect of Rhizobium inoculation, sulfur and phosphorus application on yield, yield components and nutrient uptake in chick pea (Cicer aretinum L.). African Journal of Biotechnology 7(6): 776-782.

14. Ogutcu H, Algur OF, Elkoca E \& Kantar (2008). The determination of symbiotic effectiveness of Rhizobium strains isolated from wild chickpea collected from high altitudes in Erzurum. Turkish Journal of Agriculture and Forestry 32: 241-248.

15. Siag RK (1995). Response of Kabuli chickpea to genotypes phosphorus. Indian J Agron 40(3): 4.

16. Malik MA, Cheema MA \& Khan HZ (2006). Growth and yield response of
Soyabean to seed inoculation and varying phosphorus levels. Journal of Agri Research 44: 47-53.

17. Ali H, Khan MA \& Randhawa SHA (2004). Interactive effect of seed inoculation and phosphorus application on growth and yield of chick pea.Int. Journal of Agri.And Bio 6(1): 110-112.

18. Basir A, Shah Z, Naeem M, Bakht J \& khan ZH (2008). Effect of phosphorus and farm yard manure on agronomic traits of chickpea (Cicer arietinum L.). Sarhad J Agric 24(4).

19. Singh G, Sekhon HS \& Kaur H (2012). Effect of farmyard manure, vermicompost and chemical nutrients on growth and yield of chickpea (Cicer arietinum L.). International Journal of Agricultural Research 7(2): 93-99.

20. Namvar A, Sharifi RS \& Khandan T (2011). Growth analysis and yield of chickpea (Cicer arietinum L.) in relation to organic and inorganic nitrogen fertilization. EKOLOGIJA 57(3): 97-108. 